\title{
Effect of Drying Temperature on the Chemical Qualities of Breadfruit
}

\author{
Adeoye Babatunde Kazeem", Alao Adeyinka Idowu, Famurewa John Alaba Victor
}

Department of Food Science and Technology, Federal University of Technology, Akure, Nigeria

Email address:

chembabs2007@yahoo.com (B. K. Adeoye)

${ }^{*}$ Corresponding author

\section{To cite this article:}

Adeoye Babatunde Kazeem, Alao Adeyinka Idowu, Famurewa John Alaba Victor. Effect of Drying Temperature on the Chemical Qualities of Breadfruit. International Journal of Food Science and Biotechnology. Vol. 3, No. 1, 2018, pp. 1-6. doi: 10.11648/j.ijfsb.20180301.11

Received: December 5, 2017; Accepted: December 14, 2017; Published: January 5, 2018

\begin{abstract}
Drying is described as the reduction of material moisture to the required dryness values as a definite process and it is of major interest in food processing. This study aimed at studying the influence of drying temperature on the functional and pasting properties of breadfruit flour using cabinet dryer with a view of establishing potential industrial utilization of breadfruit flour as food and food ingredients. Freshly harvested breadfruits (matured) (Artocarpus atilis) were obtained from International Institute for Tropical Agriculture (IITA), Ibadan, Oyo State, Nigeria. They were washed in clean water to remove adhering latex and dirt and were peeled, rewashed, drained and sliced manually to $3 \mathrm{~mm}$ thickness for uniformity in drying, and then dried with a cabinet dryer at 50,60 and $70^{\circ} \mathrm{C}$ respectively until constant weights were achieved, after which they were milled into flour. The flour samples were screened through a $0.20 \mathrm{~mm}$ British standard sieve. Pasting and functional properties were determined using standard methods. The variations in the functional and pasting properties were significant at $\mathrm{p}<0.05$ for temperature of 50,60 and $70^{\circ} \mathrm{C}$ respectively. The functional properties of the breadfruit flour ranged from $279.17 \%-374.73 \%$ for oil absorption capacity, $0.34 \%-0.46 \%$ for bulk density, 93.63\% - 94.70\% for dispersibility, 200\%-800\% for foaming capacity, $2 \%$ for gelation, $390.32 \%-467.04 \%$ for water absorption capacity, $137.07 \%-230.67 \%$ for swelling capacity at $55^{\circ} \mathrm{C}, 217.29 \%-333.32 \%$ for swelling capacity at $65^{\circ} \mathrm{C}, 142.73 \%-323.60 \%$ for swelling capacity at $75^{\circ} \mathrm{C}$, and $4.58 \%-6.27 \%$ for solubility at $55^{\circ} \mathrm{C}, 3.24 \%-6.40 \%$ for solubility at $65^{\circ} \mathrm{C}, 1.97 \%-6.66 \%$ for solubility at $75^{\circ} \mathrm{C}$. The pasting properties for the breadfruit flour ranged from 2309.00RVU - 3142.50RVU, 2145.5RVU-2955.5RVU, 159.5VU - 187.5RVU, 4879.00RVU 7192.50RVU, 2729.50RVU -4237.00RVU, $6.10-6.27$ and $50.40^{\circ} \mathrm{C}-53.98^{\circ} \mathrm{C}$ for peak viscosity, trough viscosity, breakdown viscosity, final viscosity, setback viscosity, peak time and pasting temperature. Respectively. There was an increase in functional and pasting properties as the temperature increases. This result showed that the breadfruit flour can be used as food ingredients.
\end{abstract}

Keywords: Artocarpus Atilis, Drying, Temperature, Functional Properties, Pasting Properties

\section{Introduction}

Matured breadfruit is a great source of carbohydrate $(84 \%)$ with starch constituting more than $60 \%$ of the total carbohydrate and an average amount of vitamin $\mathrm{C}$. The tree fruits primarily between May and August, producing 50 to 200 pieces of fruit in a year. The mature fruit is round or ovoid, 15$20 \mathrm{~cm}$ in diameter and weighing $2-10 \mathrm{~kg}$ on average. Total yearly production in Nigeria is about 10 million metric tonnes with improved agricultural practice [1]. Breadfruits are used as food and may be eaten ripe as fruit or unripe as a vegetable. Breadfruits are main staples in the Caribbean and are covered by the International Treaty on Plant Genetic Resources for Food and Agriculture [2]. In Africa, breadfruits are found in Senegal, Guinea-Bissau, Cameroun, Sierra Leone, Nigeria, Liberia and Ghana [3]. The importance of breadfruits notwithstanding, they are underutilized and neglected [4]. Their underutilization is partly due to social stigmatization, both in Nigeria and other parts of the world, as food for slaves and the poor. They are generally considered as unimportant food crops. The World Food Program encourages the incorporation of highly nutritious but neglected foods in the diets as a means of combating malnutrition [5]. To this end, research into breadfruits as dietary component has recently gained attention. 
To increase breadfruits popularity and expand their use in the food industry, Ragone [2] suggested that appropriate postharvest handling and storage should be explored. The fruit is utilized in Nigeria within 5 days of harvesting because of its short shelf life. One way to minimize post-harvest losses and increase the utilization of breadfruit is through processing into flour, which would provide a more stable storage form, as well as enhance the versatility of the fruit [7]. Functional quality of flour is important to determine its usefulness in food applications. Processing conditions have been shown to influence functional properties of flour; for example, heat processing have been found to affect the functional properties of taro flour, while drying temperature, milling procedure and particle size influenced gelatinization profiles of cassava flour [7].

Drying being one of the postharvest operation, is an energy intensive operation of some industrial significance. The drying applied to breadfruit serves as a number aims, the most important of which is the reduction of moisture content to a required level to prevent mould and microbes, allowing save storage and prevent microbial development or other harmful reaction which might lead reduction of chemical quality such as functional and pasting properties of breadfruit [8]. The most common method in drying foodstuffs is the hot air drying which causes rapidity, produces high capacity, reduces its weight and volume, and also minimizes the cost of packing, storage, and transportation [9]. Drying kinetics of food crops are generally affected by factors which include drying temperature, pretreatment method, relative humidity, and product sizes [10] and are crop specific. Thus, this research has been carried out to determine the effect of drying temperature on the function and pasting properties of breadfruit in order to improve on the chemical qualities of breadfruit.

\section{Material and Method}

\subsection{Materials}

The materials used for this research include breadfruit which was gotten International Institute of Tropical Agriculture (IITA) in Oyo State, Nigeria, weighing balance, Cabinet dryer, knife, bowls and trays. The breadfruits were thoroughly washed to remove dirt and unwanted materials. They were then peeled and washed with clean water. The breadfruit were sliced manually to $3 \mathrm{~mm}$ thickness for uniformity in drying, and then dried with a cabinet dryer at 50,60 and $70^{\circ} \mathrm{C}$ respectively until constant weight was achieved, after which they were milled into flour. The flour samples were screened through a $0.20 \mathrm{~mm}$ British standard sieve. Pasting and functional properties were determined using standard methods.

\subsection{Methods}

\subsubsection{Functional Properties Determination}

\section{Water absorption capacity}

Water absorption capacities of the flour samples were determined as described by Abbey and Ibey [11] with slight modification. One gram of flour sample mixed with $10 \mathrm{ml}$ of distilled water or oil was placed in a centrifuge tube. The suspension was agitated for one hour on a griffin flask shaker after which it was centrifuged for $15 \mathrm{~min}$ at $2200 \mathrm{rpm}$. The volume of water on the sediment water was measured. Water absorption capacity was calculated as $\mathrm{ml}$ of water absorbed per gram of flour respectively.

Oil absorption capacity

Oil Absorption Capacities were determined by using the methods of Sathe et. al. [12]. One gram of the sample was dispersed in $10 \mathrm{ml}$ of oil. The content was mixed for 5 minutes on a magnetic stirrer or using glass rod. The mixture was centrifuged at $3500 \mathrm{rpm}$ for $30 \mathrm{mins}$ and the volume of the supernatant noted. The oil absorbed was expressed as the percentage of oil absorbed per $100 \mathrm{~g}$ of the sample.

$$
O A C=\frac{\text { volume of oil absorbed }}{\text { Weight of the sample }} \times 100
$$

\section{Least gelation determination}

Least gelation concentrations for the flour samples were determined using the method of Abbey and Ibeh [7]. Samples were mixed with $5 \mathrm{ml}$ distilled water in test tubes to obtain suspensions of $2-20 \%(\mathrm{w} / \mathrm{v})$ concentration. The test tubes were heated for 1 hour in a boiling water bath, cooled rapidly under running tap water and further cooled for $2 \mathrm{hrs}$ in a refrigerator at $4^{\circ} \mathrm{C}$. The least gelation concentration was regarded as that concentration at which the sample from the inverted test tube did not fall or slip.

Swelling index

This was determined by the method described by Oladele and Aina [13]. One gram of the flour was mixed with $10 \mathrm{ml}$ distilled water in a centrifuge tube and heated at $80^{\circ} \mathrm{C}$ for 30 minutes. This was continuously shaken during the heating period. The tube was removed from the bath, wiped dry, cooled to room temperature $\left(28^{\circ} \mathrm{C}\right)$ and centrifuged for $15 \mathrm{mins}$ at $2200 \mathrm{rpm}$. The supernatant was evaporated, and the dried residue weighed to determine the solubility. The swollen sample (paste) obtained from decanting supernatant was also weighed to determine the swelling power. Swelling power was calculated as weight of the paste/weight of dry sample.

Bulk density;

The method used by Oladele and Aina [9] was utilized. A $50 \mathrm{~g}$ flour sample was put into $100 \mathrm{ml}$ measuring cylinder. The cylinder was tapped continuously until a constant volume was obtained. The bulk density $(\mathrm{g} / \mathrm{cm} 3)$ was calculated as weight of flour $(\mathrm{g})$ divided by flour volume $(\mathrm{cm} 3)$.

Dispersibility;

Dispersibility was determined using the method described by Kulkarni et al, [14]. 10g of the flour was placed inside $100 \mathrm{ml}$ measuring cylinder. Distilled water was added to reach a volume of $100 \mathrm{mland}$ it was stirred vigorously and allowed to settle for 3 hours. The volume of settled particles was recorded and subtracted from 100. The difference is recorded as the percentage dispersibility. 


$$
\text { Dispersibilty }=100-\text { vol. of settled particles }
$$

\section{Foaming}

Foam capacity was determined using Narayana and Narasimga [15] method. Two grams of the flour sample was added to $50 \mathrm{ml}$ distilled water at $30 \pm 20 \mathrm{C}$ in a $100 \mathrm{ml}$ measuring cylinder. The suspension was mixed and shaken to foam and the foam volume after 30 seconds was recorded. The foam capacity was expressed as percentage increase in volume. The foam volume was recorded 30 minutes and 60 minutes after whipping to determine the foam stability as a percentage of the initial foam volume. The volume increase (\%) was calculated using the formula:

$$
V I(\%)=\frac{A-B}{B} \times 100
$$

where,

$$
\begin{aligned}
& \mathrm{VI}=\text { Volume increase } \\
& \mathrm{A}=\text { Volume after shaking }(\mathrm{ml}) \\
& \mathrm{B}=\text { Volume before shaking }(\mathrm{ml})
\end{aligned}
$$

\subsubsection{Pasting Properties Determination}

The pasting characteristics of the Breadfruit flour samples were determined in triplicates using American Association of Cereal Chemists Approved Method 22.10 [16] with slight modifications. A Brabender viscoamylograph (Viscograph PT-100) was used to study all the pasting properties of the flour at $75 \mathrm{rpm}$ and a torque of $700 \mathrm{~g}$ equivalent to 100 Brabender units (BU) [17]. The slurry was heated from $25-$ $95^{\circ} \mathrm{C}$ at a uniform rate of $1.5^{\circ} \mathrm{C} /$ min under a constant stirring speed. The torque was continuously monitored. It was followed by cooling at a controlled rate of $1.5^{\circ} \mathrm{C} / \mathrm{min}$ to $50^{\circ} \mathrm{C}$ [17]. The cooked paste viscosity of $14 \%$ slurries in 420 $\mathrm{ml}$ water was measured. Pasting parameters including beginning of gelatinization, maximum/peak viscosity, end of final holding, break down and set back were recorded and expressed as Brabender Units (BU) [14].

\subsubsection{Analytical Procedure of the Thin Layer Drying}

Determination of moisture content of breadfruit chips;

The moisture content was determined as described by Pearson [19]. The petri-dishes were oven dried and weighed $\left(\mathrm{W}_{1}\right)$ and each labeled according to the sample contained. $5 \mathrm{~g}$ of each sample was added to the petri dishes and reweighed $\left(\mathrm{W}_{2}\right)$. The petri dishes were then transferred into the hot air oven, which was regulated to $105^{\circ} \mathrm{C}$ and they were dried to a constant weight for the duration of 4 hours. The petri-dishes were cooled in desiccators for 30 minutes after they were reweighed $\left(\mathrm{W}_{3}\right)$. This was repeated 2 or 3 times until constant weight was obtained. The analysis was carried out in triplicate. The difference in weight which corresponds to moisture content was recorded and the percentage for moisture was calculated.

$$
\begin{gathered}
\text { Moisture Content }(\%)=\frac{\text { loss in weight after drying }}{\text { weight of sample }} \times 100 \\
\frac{W_{2}-W_{3}}{W_{2}-W_{1}} \times 100
\end{gathered}
$$

Where,

$W_{1}=$ weight in grams of the empty Petri-dish

$W_{2}=$ weight of the Petri-dish and the sample before drying

$W_{3}=$ weight of the Petri-dish with the dried sample

Moisture Ratio

The change in mass data recorded from the experiment was converted to dry basis data using the moisture content value of the dried sample. The values were converted into moisture ratio using the equation below:

$$
M R=\frac{\left(M_{t}-M_{e}\right)}{\left(M_{0}-M_{e}\right)}
$$

which was simplified by some investigators $[20,21]$ because of the continuous fluctuations occurring drying processes to:

$$
M R=\frac{M_{t}}{M_{0}}
$$

where:

MR: moisture ratio, dimensionless;

$\mathrm{M}_{0}$ : initial moisture content ( $\mathrm{kg}$ water/kg dry mater);

$\mathrm{M}_{\mathrm{t}}$ : moisture content at time $\mathrm{t}(\mathrm{kg}$ water $/ \mathrm{kg}$ dry mater);

Me: equilibrium moisture content, ( $\mathrm{kg}$ water $/ \mathrm{kg}$ dry mater).

\section{Results and Discussion}

\subsection{Effect of Drying Temperature on the Functional Properties of Breadfruit}

Table 1 shows the effect of drying temperature on the functional properties of the flour samples. The oil absorption capacity of the flours increased marginally from $279.17 \%$ $374.73 \%$ as the temperature increases. According to Lahl and Braun [22], lipid binding is dependent on the surface availability of hydrophobic amino acids. Oil absorption capacity is important as oil acts as flavour retainer and gives soft texture to food, improving mouth feel [23]. Since the flours had good oil absorption capacity, it suggests the presence of good lipophilic constituents and therefore may be suitable for production of sausage, soups and cakes. Bulk density values obtained from the study ranges between $0.34 \mathrm{~g} / \mathrm{cm}^{3}$ to $0.46 \mathrm{~g} / \mathrm{cm}^{3}$. Bulk density is a measure of heaviness of a flour sample. Low values were recorded for all the flour samples. According to Nelson-Quartey et al., [24], low bulk density flour is desirable in infant food preparation. The bulk density of A. altilis flour therefore suggests they could be useful in infant food formulation. The dispersibility ranges between $93.63 \%-94.70 \%$.

Dispersibility is a measure of reconstitutes of flour or flour blend in water. The higher the dispersibility, the better the flour reconstitutes in water [13]. The recorded values showed better reconstitution of flour at lower drying temperature. Foaming results are within the range of $20 \%-80 \%$. Foam ability is reported to be related to the amount of solubilized protein [14] and the amount of polar and non-polar lipids in a sample [25]. The highest value was obtained from the breadfruit flour dried at $60^{\circ} \mathrm{C}$ and there was a significant reduction in value obtained in flour dried at $70^{\circ} \mathrm{C}$. This suggest that there was lost in the amount of solubilized 
protein at higher temperature. The result for gelatilization showed that is $2 \%$ for all the temperature. Udensi [26] indicated that gelation is an aggregation of denatured molecules which is a quality influencing the texture of food. The shows that the flour would be a good gel-forming of firming agent and would be useful in food systems such as pudding and snacks which require thickening and gelling. It might also be a useful glazing agent.

Water absorption capacity is within the range of $390.55 \%$ $467.04 \%$. In contrast, the water absorption capacities of the flours were higher than the $219 \%$ reported by NelsonQuartey et al. [24]. The water absorption capacity of the A. altilis flours $(390.55 \%$ - 467.04\%) was within the range reported for cassava pulp flour $(171.3 \%$ - 551.2\%); Water absorption capacity of flour is a useful indicator of whether protein can be incorporated with the aqueous food formulations, especially those involving dough handling [27]. The high water absorption capacity of the flour suggests they could be useful in soup formulations [28].

The swelling power is within the range of $137.07 \%$ $281.76 \%$ at $55^{\circ} \mathrm{C}, 217.29 \%-333.32 \%$ at $65^{\circ} \mathrm{C}$ and $142.73 \%$ - $323.60 \%$ at $75^{\circ} \mathrm{C}$. The swelling power of breadfruit flour increases with increase in temperature and it is a measure of hydration capacity, because the determination is a weight measure off swollen starch granules and their occluded water. Food eating quality is often connected with the retention of water in the swollen starch granules [29]. Since the swollen power is high, it suggests that it may find application in noodles production [30]. The solubility measures with increases in temperature. The results are within the range of $4.58 \%-6.27 \%$ at $55^{\circ} \mathrm{C}, 3.24 \%-6.40 \%$ at $65^{\circ} \mathrm{C}$ and $1.97 \%$ $6.66 \%$ at $75^{\circ} \mathrm{C}$. On the other hand, Baafi and Safo-Kantanka [31] reported solubility ranging between $7.57 \%$ and $10.46 \%$ for cassava. According to these authors, solubility of flour is an indicator of its quality.

Table 1. Functional properties of breadfruit flour dried at three different temperatures.

\begin{tabular}{|c|c|c|c|c|c|c|}
\hline TEMP $^{\circ} \mathrm{C}$ & OAC & BULK DENSITY & DISPERSIBILITY & FOAMING & GELATION & WAC \\
\hline 50 & $279.17 \pm 1.37^{\mathrm{c}}$ & $0.46 \pm 0.003^{\mathrm{a}}$ & $94.70 \pm 0.100^{\mathrm{a}}$ & $400.00 \pm 0.00^{\mathrm{a}}$ & $2.00 \pm 0.00^{\mathrm{a}}$ & $390.55 \pm 0.28^{\mathrm{a}}$ \\
\hline 60 & $374.73 \pm 1.10^{\mathrm{a}}$ & $0.42 \pm 0.004^{b}$ & $94.10 \pm 0.10^{\mathrm{b}}$ & $800.00 \pm 0.00^{a}$ & $2.00 \pm 0.00^{a}$ & $467.04 \pm 0.70^{\mathrm{a}}$ \\
\hline 70 & $321.77 \pm 1.15^{b}$ & $0.34 \pm 0.000^{\mathrm{c}}$ & $93.63 \pm 0.15^{\mathrm{c}}$ & $200.00 \pm 0.00^{\mathrm{a}}$ & $2.00 \pm 0.00^{\mathrm{a}}$ & $392.32 \pm 0.58^{b}$ \\
\hline
\end{tabular}

Table 1. Continued.

\begin{tabular}{|c|c|c|c|c|c|c|}
\hline \multirow{2}{*}{ TEMP $^{\circ} \mathrm{C}$} & \multicolumn{3}{|c|}{ SWELLING POWER } & \multicolumn{3}{|l|}{ SOLUBILITY } \\
\hline & $55^{\circ} \mathrm{C}$ & $65^{\circ} \mathrm{C}$ & $75^{\circ} \mathrm{C}$ & $55^{\circ} \mathrm{C}$ & $65^{\circ} \mathrm{C}$ & $75^{\circ} \mathrm{C}$ \\
\hline 50 & $137.07 \pm 0.12^{\mathrm{c}}$ & $219.71 \pm 0.54^{b}$ & $2445.10 \pm 0.10^{b}$ & $4.58 \pm 0.01^{\mathrm{c}}$ & $3.24 \pm 0.03^{\mathrm{c}}$ & $6.66 \pm 0.01^{\mathrm{a}}$ \\
\hline 60 & $281.76 \pm 0.50^{\mathrm{a}}$ & $333.32 \pm 0.69^{\mathrm{a}}$ & $323.60 \pm 0.61^{\mathrm{a}}$ & $5.30 \pm 0.016^{\mathrm{b}}$ & $4.10 \pm 0.04^{b}$ & $3.16 \pm 0.071^{\mathrm{b}}$ \\
\hline 70 & $230.67 \pm 0.69^{b}$ & $217.29 \pm 0.42^{\mathrm{c}}$ & $142.73 \pm 0.96^{c}$ & $6.27 \pm 0.01^{\mathrm{a}}$ & $6.40 \pm 0.02^{\mathrm{a}}$ & $1.97 \pm 0.015^{\mathrm{c}}$ \\
\hline
\end{tabular}

\subsection{Effect of Drying Temperature on the Pasting Properties of Breadfruit}

Table 1 shows the effect of drying temperature on the pasting properties of the flour samples. The pasting temperature was found to vary from $50.40^{\circ} \mathrm{C}-53.98^{\circ} \mathrm{C}$. The pasting temperature depends on the size of starch granules, small granules are more resistant to rapture and loss of molecular order, so this might explain the relatively high pasting temperature. The ability of starch to imbibe water and swell is primarily dependent on the pasting temperature. The higher the pasting temperature, the faster the tendency for the paste to be formed [32]. Hence, in the presence of water and heat, starch granules swell and form paste by imbibing water.

The peak viscosity is within the range of 2330.00RVU to
3142.50RVU. The higher peak viscosity of the flour might be related to the proportion of starch in the flour, the ratio of amylose to amylopectin and the resistance of its starch granules to swelling. The breakdown viscosity $(\mathrm{BV})$ which is a measure of cooked flour to disintegration was found to be between the ranges of $159.5 \mathrm{RVU}$ to $187.5 \mathrm{RVU}$. Final viscosity which indicates the ability of the flour to form a viscous paste ranged between 4879RVU to 7192.50RVU. The increase in viscosity which occurs as a result of cooling is mainly due to re-association between starch molecules, especially amylose.

The setback was between the ranges of $2729.50 \mathrm{RVU}$ to 4237.00RVU, the higher the setback value, the lower the retro gradation during cooling and the lower the staling rate of the products made from the starch [33].

Table 2. Pasting properties of breadfruit flour dried at three different temperatures.

\begin{tabular}{lllll}
\hline TEMP $^{\circ}$ C & PEAK VISCOSITY & TROUGH VISCOSITY & BREAKDOWN VISCOSITY & FINAL VISCOSITY \\
\hline 50 & $2330.00 \pm 182.00^{\mathrm{b}}$ & $2145.5 \pm 217.50^{\mathrm{b}}$ & $184.5 \pm 35.5^{\mathrm{a}}$ & $5135.00 \pm 279.00^{\mathrm{b}}$ \\
60 & $3142.50 \pm 194.50^{\mathrm{a}}$ & $2955.5 \pm 270.5^{\mathrm{a}}$ & $187.5 \pm 76.0^{\mathrm{a}}$ & $7192.50 \pm 149.50^{\mathrm{a}}$ \\
70 & $2309.00 \pm 96.00^{\mathrm{b}}$ & $2149.5 \pm 106.50^{\mathrm{b}}$ & $159.5 \pm 10.5^{\mathrm{a}}$ & $4879.00 \pm 85.00^{\mathrm{b}}$ \\
\hline
\end{tabular}

Table 2. Continued.

\begin{tabular}{llll}
\hline TEMP $^{\circ}$ C & SETBACK VISCOSITY & PEAK TIME & PASTING TEMP'C \\
\hline 50 & $2989.5 \pm 61.50^{\mathrm{b}}$ & $6.10 \pm 0.30^{\mathrm{a}}$ & $50.95 \pm 0.25^{\mathrm{a}}$ \\
60 & $4237.00 \pm 420.00^{\mathrm{a}}$ & $6.27 \pm 0.60^{\mathrm{a}}$ & $50.40 \pm 0.20^{\mathrm{a}}$ \\
70 & $2729.50 \pm 191.50^{\mathrm{b}}$ & $6.24 \pm 0.64^{\mathrm{a}}$ & $53.98 \pm 3.38^{\mathrm{a}}$ \\
\hline
\end{tabular}




\section{Conclusion}

This study has clearly revealed the influence of varying temperature on functional and pasting temperature of breadfruit species (A. altilis,). Even though, the species have been well characterized in terms of their botany, traditional food uses and proximate composition, there is insufficient information on their functional properties and pasting characteristics of the species in relation to different drying temperature. Available literature did not provide sufficient information about their potential for modern food and industrial uses. The result obtained from pasting and functional properties respectively indicate that the breadfruit flour can be used as food ingredients and also play important food security roles in the countries where they are found.

\section{References}

[1] Bakare, H. A., Osundahunsi, O. F., Adegunwa, M. O. (2012): Composition and pasting properties of breadfruit (Artocarpus Communis Forst) from south-west states of Nigeria. Nig. Food J. 30, 11-17.

[2] Ragone, D. (2007). Breadfruit: Diversity, Conservation and Potential. Proc. 1st International Symposium on Breadfruit Research and Development. Acta Horticulturae 757: 19-30.

[3] Burkill, H. M. (1997). The Useful Plants of West Tropical Africa. Royal Botanic Gardens, Kew 4 (2). pp: 160-161. 960.

[4] Omobuwajo T. O (2003). Compositional characteristics and sensory quality of biscuits, prawn crackers and fried chips. $J$. Innovative Food Sci. Emerging Technol., 4 (2): 219-225.

[5] Muriel, R. and Gillick, M. D. (2000). Rethinking the role of tube feeding in patients with Advanced Dementia. The new England Journal of Medicine. 342 (3): 206-210.

[6] Tijani, A. O., Bakare, H. A., Babajide, J. M., Omemu A. M. (2017). The effect of processing parameters on the functional and pasting properties of breadfruit (Artocarpus Altilis) "elubo" flour. Croat. J. Food Sci. Technol. 9 (1) 31-39.

[7] Olatunde, G. O., Henshaw, F. O., Idowu, M. A. and Tomlins, K. (2016). Quality attributes of sweet potato flour as influenced by variety, pretreatment and drying method. Food Science and Nutrition. 4 (4), 623-635.

[8] Quartermain, A. (2006). Underutilised Species - Policies and Strategies. Information Bulletin No. 15. National Agricultural Research Institute, Lae, Papua New Guinea.

[9] Samira, N., Nasrin, E., Arefe, P. N. and Majid, G. F. (2016). Mathematical modeling of drying of potato slices in a forced convective dryer based on important parameters. Food Science \& Nutrition. 4 (1): 110-118.

[10] Kudra, T (2004). Energy aspect of drying. Journal of Drying Technology 22 (5) 917- 932.

[11] Abbey, B. W. and Ibeh, S. O. (1988). Functional properties of raw and heat processed cowpea (Vigna unguiculata, walp) flour. Journal of Food Science. 53 (6): 1775 - 1791.
[12] Sathe, S. K., Deshpande, S. S. and Salunkhe, D. K. (1982). Functional properties of winged bean (Psophocarpus tetragonolobus, L) proteins. Journal of Food Science 47: 503506.

[13] Oladele, A. K. and Aina, J. O. (2007). Chemical composition and functional properties of flour produced from two varieties of tigernut (Cyperus esculentus) African Journal of Biotechnology 6 (21): 2473-2476.

[14] Kulkarni, K. D., Kulkarni, D. N and Ingle, U. M. (1991). Sorghum Malted and soya bean weaning food formulations: Preparation, functional properties and nutritive value. Food Nutr. Bull., 13: 322-327.

[15] Narayana, K and Narasimga, R. N. M. S. (1982). Functional properties of raw and heat processed winged bean flour. Journal of Food Science 47: 1534-1538.

[16] American Association of Cereal Chemists (1983). Approved Methods of the AACC, 8th Edition. Method 22-10, approved May 1960, revised October 1982; The Association: St. Paul, MN.

[17] Demiate, I. M., Oetterer, M. and Wosiacki, G. (2001). Characterization of chestnut (castenea sativa, Mill) starch for Industrial Utilization. Brazilan Archives of Biology and Technology 44: 1 .

[18] Damardjati, D. S. and Luh, B. S. (1987). Physicochemical properties of Extrusion-cooked rice breakfast cereals. Proceeding of the 7th World Congress of Food Science and Technology. Trends in Food Processing 1: Membrane Filtration Technology and Thermal Processing and Quality of Foods. Singapore. October. Ghee et al (Eds.). pp. 251264.

[19] Pearson D (1976). The chemical analysis of food. (7th ed.) Edinburgh; New York: Churchill Livingstone.

[20] Togrul, I. and Pehlivan, D. (2002). Mathematical modeling of solar drying of apricots in thin layers. Journal of Food Engineering 55 (3): 209-216.

[21] Midilli, A., Kucuk, H., (2003). Mathematical Modeling of thin layer drying of pistachio by using solar energy. Energy Conversion and Management. 44 (7): 1111-1122.

[22] Lahl, W. J. and Braun, S. D. (1994). Enzymatic production of protein hydrolysates for food use. Food Technology 48: 68-71.

[23] Ubbor, S. C. and Akobundu, E. N. T. (2009). Quality Characteristics of Cookies from Composite Flours of Watermelon Seed, Cassava and Wheat. Pakistan Journal of Nutrition, 8: 1097-1102.

[24] Nelson-Quartey, F. C., Amagloh, F. K., Oduro, I. and Ellis, W. O. (2007). Formulation of an infant food based on breadfruit (Artocarpus altilis) and breadnut (Artocarpus camansi). Acta Horticulturae. (ISHS) 757: 212-224.

[25] Nwokolo, E. (1985). Nutritional quality of the seeds of the African breadfruit (Treculia africana Decne). Tropical Science 27: $39-47$

[26] Udensi (2001). Effect of traditional processing on the physiochemical properties of mucuna cochichinsis Mucuna Utilis Rome. Journal of Science of Agriculture, Food Technology and environmental Vol 1: 133-137. 
[27] Osungbaro, T. O, Jimoh, D. and Osundeyi, E. (2010). Functional and Pasting Properties of Composite CassavaSorgum Flour Meals. Agriculture and Biology Journal of North America 1 (4): 715-720.

[28] Olaofe, O., Adeyemi, F. O. and Adediran, G. O. (1994). Amino acid and mineral compositions and functional properties of some oil seeds. J. Agric. Food Chem., 42: 878881.

[29] Rickard, J. E., Blanshard, J. M. V., Asaoka, M. (1992). Effect of curtivar and growth season on the gelatinization properties of cassava (Manihot esculenta) starch. J. Sci. Food Agric, (59) 53-58.

[30] McComick, K. M., Panozzo, J. F. and Hong, S. H. (1991). A swelling power test for selecting potential noodle quality wheats. Australian Journal of Agricultural Research 42 (3): 317-323.

[31] Baafi, E and Safo-Kantanka, O (2007). Effect of Genotype, Age and Location on Cassava Starch Yield and Quality. Journal of Agronomy, 6: 581-585.

[32] Dreher, M. L and Berry, J. W. (1983). Buffalo gourd root starch. Part I. Properties and structure. Starch/Starke 35: 7681.

[33] Adeyemi, I. A. and Idowu, M. A. (1990). Evaluation of pregelatinized Maize flour in the development of 'Maissa'-a baked product. Nigerian Food Journal.: 63-73. 